\title{
Balancing Procedures and Outcomes Within Democratic Theory: Core Values and Judicial Review
}

\author{
Corey Brettschneider
}

Brown University

\begin{abstract}
Democratic theorists often distinguish between two views of democratic procedures. 'Outcomes theorists' emphasize the instrumental nature of these procedures and argue that they are only valuable because they tend to produce good outcomes. In contrast, 'proceduralists' emphasize the intrinsic value of democratic procedures, for instance, on the grounds that they are fair. In this paper. I argue that we should reject pure versions of these two theories in favor of an understanding of the democratic ideal that recognizes a commitment to both intrinsically valuable democratic procedures and democratic outcomes. In instances in which there is a conflict between these two commitments, I suggest they must be balanced. This balancing approach offers a justification of judicial review on the grounds that it potentially limits outcomes that undermine democracy. But judicial review is not justifiable in any instance in which a bad democratic outcome results from democratic procedures. When the loss that would result from overturning a democratic procedure is greater than the gain to democracy that would result from ensuring against an undemocratic outcome; judicial review is not justifiable. Loss or gain to democracy is defined by the negative or positive impact of each action on the core democratic values of equality and autonomy, aspects of the democratic ideal. Even when judicial review is justified, the fact that it overturns intrinsically valuable procedures suggests that such review is never ideal from the standpoint of democracy.
\end{abstract}

Democratic theorists have explained why certain rights to participate in the democratic process are fundamental. Without a 'procedural right' to vote, for instance, citizens could not be guaranteed the ability to participate in democratic procedures necessary for self-rule. ${ }^{1}$ However, protection of procedural rights does not guarantee policy outcomes that honor 'substative rights', such as the right to privacy, in fact, judicial review is often employed to protect substantive rights that have been violated through standard democratic procedure. For instance, the United States Supreme Court in Lawrence v. Texas (2003) relied on the doctrine of substantive due process and the equal protection clause to strike down a Texas law that criminalized homosexual sex between consenting adults. In doing so, the Court extended the right of privacy to gay citizens. Can democratic theory account for substantive rights as essential to democratic legitimacy, even when democratic procedures do not produce them and when they are not essential to the functioning of these procedures? If it can, is judicial review in defense of these rights justifiable? In answering these questions, democratic theory is split into two camps.

Theorists of pure proceduralism contend that democracy's meaning lies in answering what Jeremy Waldron (2001) regards as the fundamental question of democratic legitimacy: 'who decides?' ${ }^{2}$ By 'proceduralism' I mean the general view that 
the source for democratic legitimacy is found in citizens' participation in a process or a series of processes in which they each have equal power in decision making. Procedural views are pure when they locate the standard of legitimacy for the outcomes of the process entirely in the fact of whether a legitimate procedure was followed. On such a view, there is nothing intrinsically democratic about the outcomes of such decisions aside from the fact that they were produced by democratic procedures. Therefore, these theorists emphasize developing accounts of fair procedure (Christiano, 1996, and Ely, 1980). However, when democratic procedures result in outcomes that violate substantive rights, such as the rights at issue in Lawrence, these thinkers suggest that democratic legitimacy has not been violated. Just because a decision might be unjust does not entail that it is undemocratic.

In contrast to pure proceduralists, who locate democracy in a fair procedure with intrinsic value, another group I call 'pure outcomes' theorists view democratic procedures as solely instrumental (Estlund, 1997). For these thinkers, the value of democratic procedures is that they tend to produce good outcomes. Specifically, good outcomes typically include those protecting basic rights. When these rights are violated, therefore, outcomes theorists believe the results of democratic procedures should be overturned. Ronald Dworkin (1996) argues that good outcomes are rightly regarded as democratic if they respect the equal status of citizens as well as their autonomy. To extrapolate, on the 'pure outcomes' view, the Court's decision in Lawrence is potentially defensible on democratic grounds since it promotes autonomy by enhancing citizens' decision-making ability and ensures equality by extending the privacy protections granted to heterosexual citizens to homosexuals.

In contrast to the above two views, I argue in this essay, however, that a good theory of democracy will not choose between a pure emphasis on either outcome or procedure but should incorporate both. Contra pure outcomes theorists, I suggest that decisions made through democratic procedures have intrinsic value because they allow persons to exercise their own autonomy in a way consistent with their status as equal citizens. Contra pure proceduralists, however, I suggest that at times procedures can produce outcomes that undermine persons' autonomy and equal status. In such cases, the very democratic rationale for fair procedures has been undermined. ${ }^{3}$ My aim to incorporate both outcomes-based and procedural requirements into an account of democracy places my view in broad agreement with theorists such as Jürgen Habermas (1998), who stresses the 'cooriginality' of substantive rights and democratic procedures, and David Beetham, whose writing on international human rights (1999) has also stressed that democracy is an ideal requiring both participatory guarantees and basic rights. I want to focus, however, on a subsequent question that follows from our common starting point: what is to be done in non-ideal circumstances when a conflict emerges between democratic procedures and democratic outcomes? Specifically, what does democracy require when democratic procedures result in legislation undermining democratic rights? And what role should the counter-majoritarian institution of judicial review play in such circumstances?

My thesis is that there is no a priori answer for a polity seeking to enact the most democratic policy when it is faced with a tension between democratic outcomes 
and democratic procedures. I thus reject the pure proceduralist view that democratic procedures are the source of legitimacy, whatever their outcomes, and I also reject the pure outcomes-based view, that procedures are always rightly overturned when they produce undemocratic outcomes. It is necessary to look to specific examples to weigh whether a fair procedure is rightly overturned in the name of democracy. I argue that this process will involve striking a balance between outcomes and proceduralist views by appealing to the primary justification of democracy: namely, the core values of equality and autonomy. ${ }^{4}$ In short, a good theory of democracy will embrace a commitment to democratic procedures while recognizing their limits. When democratic procedures greatly threaten the status of democratic citizens as free and equal, they are rightly overridden by the process of judicial review in the name of democracy. But decisions that overturn democratic procedures also undermine the core values of democracy because they overrule decisions made by a democratic people. Therefore, even when a democratic procedure results in an undemocratic outcome, judicial review is not automatically justifiable; the loss that would result from overturning a democratic procedure should never be greater than the gain to democracy that would result from ensuring against an undemocratic outcome. Furthermore, on the balanced approach I propose, even when democracy requires overriding decisions that resulted from democratic procedures, democrats should nonetheless acknowledge that such an action falls short of the democratic ideal.

In order to highlight the significance of conflicts between democratic procedures and democratic outcomes, I posit examples of both. For instance, I identify the protection of privacy as a paradigmatic democratic outcome. ${ }^{5}$ Drawing on the most familiar idea of democratic procedure and the work of Jeremy Waldron (2001), I posit majority rule as a paradigmatic democratic procedure. I bracket debate over what counts as a democratic procedure or a democratic outcome in order to explore what is to be done when outcomes and procedures conflict.

\section{The Question: Margaret's Dilemma}

In order to highlight the advantages of an account of democracy that embraces the tension between outcome and procedure, it is helpful to look to a hypothetical example. Specifically, I want to illustrate the dilemma that arises when a person must make the most democratic decision in the face of a conflict between a democratic outcome and procedure. Margaret is a democratic theorist who finds herself on the Supreme Court in a country that has both judicial review and a national plebiscite system. She is confronted with the question of whether or not she should strike down a plebiscite. ${ }^{6}$ Her concern is solely to determine whether striking down the plebiscite would be the right decision from the standpoint of democracy.

Margaret finds herself surrounded by two justices (Justice Process and Justice Results) who both think they can answer this question a priori. On the one hand, Process offers the following argument: 'The people have already spoken. If we are going to make a democratic decision, we must let people determine for themselves what is right. The best way to do this is to maximize the number of opinions taken into account and then let the outcome stand. Any intervention on our part would violate the democratic ideal, and hence is a loss to democracy.' 
Margaret's other colleague, Results, argues as follows: 'Democracy is fundamentally about certain core values underlying self-government. We should ask whether the plebiscite's outcome conflicts with these values. If it does undermine them, we should strike down even a majority's decision - not on our own behalf, but in the name of democracy.'

My view is that both Process' statement (an example of pure proceduralist theory) and Results' statement (an example of pure democratic outcomes theory) suffer from the same flaw. Before they look at any particular case, both Process and Results know whether they will be more concerned with the legitimacy of its procedure or the legitimacy of its outcome. For Justice Process, the question of whether or not the plebiscite is democratic depends entirely on whether majoritarian procedure was followed. For Justice Results, the issue is entirely about whether the outcome supports core democratic values; the procedure used to determine the outcome is irrelevant.

Although her fellow justices would advise otherwise, I think Margaret should consider carefully the details of the case from the perspective of both procedure and outcome before making up her mind. If the issue in the plebiscite is passed by the national plebiscite system, then there is reason to think it has at least some weight democratically. As I argue below, the very fact that actual persons have made a decision through a democratic procedure has weight democratically because political autonomy demands deference to actual persons' decisions. If such a decision affirms the core values of democracy and the notion that all citizens should be free and equal, then all the better for democracy. But as I argue in my critique of pure procedual theories, if the outcome of this decision is such that it undermines the core values, then a dilemma arises. When a democratic procedure fundamentally threatens citizens' democratic status, there is a loss to democracy. This is a problem for Margaret because the result is a tension internal to democracy, between substantive and procedural implications of the core values. Margaret is left with a choice that requires her to determine which decision has the least harmful impact on democracy by balancing procedural and substantive values. Although her job is thereby more difficult than that of her colleagues, by taking this approach, Margaret is more transparent about the inevitable value conflicts that occur within a good democratic theory.

\section{The Limits of Purely Outcomes Based Theories}

Since I contend that there are some substantive outcomes that must be protected in a legitimate democratic polity, at first glance it might seem my position is the same as Justice Results'. After all, one might think, any theory that embraces the notion that democracy requires substantive constraints must see procedure as merely instrumental to outcomes of those procedures, which protect the core values. If this were the case, Results would be right to claim that Margaret's first concern should be to promote good outcomes consistent with both the core values and the democratic rights they demand. The value of any particular procedure would depend entirely on whether it promoted these outcomes. Majoritarian procedures, to the extent that they violate the core values, could be written off as undemocratic. 
One theoretical defense of Results' view is developed by Ronald Dworkin (1996). He argues that since the meaning of democracy fundamentally depends on the idea that citizens have equal status, the sole question in assessing a policy's democratic legitimacy is whether or not this status has been protected or undermined. When judicial review overrides either the decision of the legislature or a plebiscite, there is, in his words, 'no moral cost' to democracy. No citizen is 'worse off' from the standpoint of democracy. ${ }^{7}$ Dworkin therefore gives a wholehearted endorsement to Results' solution to Margaret's dilemma. Margaret should have no qualms about overriding a majority decision when a majority fails to enact a democratic outcome. This could take place in instances in which most people voting are indifferent to the idea of a democratic outcome that reflects equal status. An override might also be necessary when voters attempt to enact policy that respects equal status but fail to do so. Since institutional structures in a democracy are designed to 'produce the best answers to the essentially moral question of what the democratic conditions actually are', Margaret acts democratically when she is sure she can better produce a democratic outcome than a majority of citizens. ${ }^{8}$

The merit of the pure outcomes view lies in the recognition that any evaluation of the degree to which a policy outcome is democratic must make reference to democratic values. For Dworkin (1996), this lies in the recognition that all citizens in a democracy must have equal status. I agree with Dworkin that at times democratic procedures can undermine this value as well as others such as autonomy, which is essential to the meaning of self-rule. In such cases there is a loss to democracy. But an exclusive focus on outcomes neglects the intrinsic democratic value of majoritarian procedures. The value of political autonomy requires that actual persons have a role in deciding which laws will govern them and this value should be protected on democratic grounds, in part by striking down legislation that threatens the very rights that guarantee citizens the ability to make personal autonomous decisions. But the value of autonomy is also realized through political rights that allow individuals to participate in policy making. At minimum, there is an added value to a good democratic outcome when a majority actively affirms this outcome. For Results and other pure outcomes based views, however, the added advantage and the intrinsic value of individual participation are neglected in favor of what I regard as an excessive focus on democratic outcomes. This view is too strong in that it fails to see that there is a 'loss to democracy' that occurs every time a non-majoritarian institution is needed to protect the substantive rights of democracy.

Democratic procedures, like democratic outcomes, have intrinsic worth when they reflect the core values of democracy, which are autonomy, equality and reciprocity. We should treat citizens as autonomous in order to respect their status as selfgoverning, but do so in a way that recognizes that they are equally autonomous. The value of reciprocity suggests a manner of argument in which citizens regard each other as autonomous and equal. These three core values, manifested in both procedural and substantive guarantees, comprise the democratic ideal. We should regard these three core values, on my account, as the normative basis for procedural and substantive guarantees because they express what is required to recognize the status of democratic citizens as free and equal. Rights of participation in democratic procedures, as well as substantive rights, should both be justified with 
reference to this ideal of democratic authority. Procedural rights express what it means for rule to be by the people, while substantive guarantees express the ideal of democratic rule for the people. ${ }^{9}$

The importance of actual participation by persons in a majoritarian procedure is best demonstrated by comparing the ideal circumstances of democracy, in which majorities affirm democratic outcomes, to those present in Margaret's dilemma. In her particular case, Margaret must decide whether to overturn a bad democratic outcome. From the standpoint of democracy, it is better when a majority does not make a mistake in the first place. In such cases, actual persons affirm their status as citizens by endorsing the core values of democracy.

Consider, in contrast, Ronald Dworkin's analysis of how Texas v. Johnson (1989) can be justified on democratic grounds. In this case, the Court considered whether the first amendment requires a judicial override of a Texas law prohibiting citizens from burning the American flag. The Court reasoned that since the Texas law restricted politically symbolic speech, the First Amendment required them to strike it down. In Dworkin's view, such a decision was not a loss to democracy but a gain. In his words:

No one's power to participate in a self-governing community has been worsened, because everyone's power in that respect has been improved. No one's equality has been compromised, because equality, in the only pertinent sense, has been strengthened. No one has been cheated of the ethical advantages of a role in principled deliberation if he or she had a chance to participate in the public discussion about whether the decision was right. (1996, p. 32)

For the purpose of argument, let us stipulate that an outcome like the one Dworkin defends - one that protects free speech - the core democratic value of political autonomy. But given that this same outcome can be protected by a variety of procedures, surely there would have been added value if a plebiscite rather than a court had secured it or, indeed, if the Texas legislature had never passed the law restricting free speech in the first place. In fact, from the standpoint of democracy, it would have been even better if the citizens of Texas or the American public had affirmed the free speech right to burn the flag through a plebiscite.

Specifically, the added value that comes when good democratic outcomes are affirmed by majorities, for instance through a plebiscite, is that there is actual endorsement, or what some would call ratification, of the core values of democracy by actual persons. Here the value of political autonomy is reflected in two senses. First, it is reflected in the participation of actual persons in policy making. If democratic citizens have the status of rulers, there should be some value in looking to what they actually think when it comes to ruling. The value of autonomy demands a respect for the capacity to rule, and the exercise of this capacity is embodied in actual persons. Second, it is reflected in an outcome that affirms the very value that justifies their participating in the first place. In the quote above, Dworkin claims that no individuals were 'cheated' out of a chance to participate since, regardless of the Court's override, they were able participate in 'public discussion'. However, Dworkin overlooks the fact that the value of autonomy 
would have been enhanced if actual political participation had involved ratifying a decision that was right from the standpoint of democracy.

The added significance that comes with a majority's or supra-majority's affirmation of the core values points to the fact that procedure has some intrinsic worth. Specifically, the intrinsic value of procedure is located in its relationship to a core democratic right. Following Jeremy Waldron, I call this the 'right to participate' (2001). Like democratic rights that are substantive and therefore affect outcomes, it is a direct manifestation of the core values of political autonomy and equality. When citizens participate in political decision-making, they exercise their autonomy in the very fact that they have made a decision. Their equality is recognized when their vote is regarded as equal to all of their fellow citizens' votes (Waldron, 2001). ${ }^{10}$

The intrinsic value of certain democratic outcomes and of democratic procedures explains why these two aspects of democracy are rightly balanced. In cases where majorities undermine the very values of democracy that give rise to their right to participate and decide, they are rightly regarded as having, on balance, acted undemocratically. Occasionally, the threat to core values is so extreme that it calls for a correction. When a democratic correction is made, it results in some loss to democracy. This is why Results' approach to judicial review cannot be sustained. It is too cavalier in looking to the outcome and ignoring the process by which it was reached. The very fact that a majority made a decision gives it weight from the standpoint of the values of democracy. Ultimately, the right to participate might be outweighed by values more fundamental, though each time these values trump democratic procedure, it must be recognized that there is a loss to democracy.

In a recent article, Alon Harel defends the pure outcomes theory and the 'no loss' thesis on the grounds that when the Court enforces a democratic outcome, it is actually making citizens live up to their deepest convictions (Harel, 2003). Since citizens embrace the core values of democracy, Harel suggests that they really do participate in judicial overrides because their deepest convictions are ensured at the policy level. On my view, however, Harel fails to distinguish between the values and policies that are essential to democracy's meaning and that citizens should accept and those values and policies that they do accept. Some actual persons reject the core values, and a good democratic theory should not make the mistaken claim that such persons really will the right democratic outcomes or participate in them; rather, the recognition that democracy is about core values sometimes demands overriding individuals' beliefs when these values are deeply threatened. In such circumstances, there is a loss to the democratic ideal. When a polity affirms democratic values, it ratifies the core principles of democracy at the same time that persons exercise the right to participate. Such instances should be celebrated as gains to democracy. In contrast, when majoritarian decisions must be overruled, the very need for correction of such decisions suggests that the polity has acted in a less than ideal manner. Such mistakes by the polity are a loss to democracy.

So far I have explained why the notion that democracy requires the protection of individual rights is consistent with the acknowledgement that there is an intrinsic value to participation in majoritarian procedures. In the next section I consider an argument that these two claims are incompatible. 


\section{The Failure of Pure Procedural Theories}

Majoritarianism - Justice Process' view - is perhaps the most commonly held account of what it means to decide according to a democratic procedure. In defending majoritarianism as a procedural aspect of democracy, as well as in uncovering its weaknesses as a sufficient account of democracy, it is helpful to examine a prominent defense of proceduralism. Some pure proceduralists think that majoritarianism must not only be democracy's core principle but an exclusive principle in political decision-making. Although they acknowledge that some individuals might know more about what is true or just, they still believe that majorities must be deferred to, even when they make decisions that are incorrect or unjust. Pure proceduralists suggest that collective self-government calls for citizens to be granted equal status in their right to make decisions. They also argue, as I have, that the value of political autonomy is enhanced when majoritarian procedures actually result in an enacted policy that is not overturned. In our example Justice Process thus concludes that judicial review is not merely a loss to democracy but incompatible with it. Non-majoritarian decisions violate the right to participate and are therefore incompatible with recognizing the intrinsic value of majoritarianism.

To some degree these arguments are consistent with the points I have made against pure democratic outcomes theorists. But I think the conclusion that any instance of judicial review is a loss to democracy is flawed in the same way that pure outcomes theories are. Pure majoritarianism, which claims that whatever outcomes result from a majority vote are democratic, fails to recognize that some of these outcomes could undermine core values of democracy. The core values reflect the status of a people that rules itself. They thus provide the very justification for the right to participate itself. When majoritarian procedures result in outcomes that disenfranchise part of the citizenry, not only are the core values undermined, but the right to participate itself is also undermined. Such an outcome would clearly be a loss to democracy.

The core values can also be undermined when democratic rights besides the right to participate are attacked. Some such rights might be regarded as preconditions of democracy. For instance, many democratic theorists have argued that restrictions on free speech would detract from citizens' ability to formulate developed democratic opinions and would cut off access to the information - both factual and moral - needed for a good democratic decision. Outcomes of majoritarian procedure that undermine speech are thus rightly regarded as losses to democracy. In addition, I regard attacks on democratically justified privacy (for instance, restrictions on whom one can marry) as examples of attacks on the core values of democracy that are substantive rather than procedural.

Ultimately, my concern is to show that attacks on democratic rights so undermine the core values of democracy that majoritarian procedures should sometimes be overturned to protect these rights. Before I make this argument, however, which is clearly in tension with the purely proceduralist view, I want to make a less ambitious point. As I stated, the pure proceduralist not only rejects judicial review but also fails to recognize that violations of rights required by the core values can ever be losses to democracy. In the same way that Dworkin fails to recognize how majoritarian procedure that affirms good democratic outcomes 
adds to democratic legitimacy, there is a flaw in the pure procedural view that unreasonable violations of the core values by majorities are no worse from a democratic standpoint than affirmation of these values by majorities. A majoritarian decision that undermines free speech, for instance, is surely of less democratic value (all other things being equal) than one that does not undermine free speech. The problem with pure proceduralist views (including majoritarianism and more complex theories of procedure) is that they identify democracy with the value of participation but exaggerate the importance of participation by failing to give any weight to democratic outcomes (Brettschneider, forthcoming).

So far I have shown the problems with purely procedure-based and purely outcomes-based theories of democracy. In particular, I have suggested why weight must be given to both procedure and outcomes in accord with their case-by-case impact on the core values of democracy. Both proceduralist and outcomes theorists, however, can offer a response to this account by amending their theories. Procedural theorists could recognize that outcomes have weight, but never more weight than the procedures themselves. Similarly, outcomes theorists could recognize that procedures have weight, but never more than outcomes. However, I reject these amended positions in the next section.

\section{Impure Procedure and Outcomes Based Theories}

Even if one rejects purely outcomes-based or purely procedure-based theories of democracy, there is still the question of how best to make a democratic decision when majoritarian procedures produce bad democratic outcomes. One can recognize that in such a circumstance there is inevitably a loss to democracy. But the democratic theorist's task is to offer an explanation of how this loss can be minimized. To illustrate, consider an instance of Margaret's dilemma. For the purposes of argument, assume that free speech is a core democratic right and that the decision to restrict flag burners inevitably violates that right. If Margaret is confronted with legislation that restricts flag burning, regardless of her decision, she cannot avoid a loss to democracy. Any decision to uphold the restriction would undermine democracy because the legislation results in a bad democratic outcome. On the other hand, if Margaret strikes down the legislation, she will have struck a blow to the right to participate. Accordingly, the question for Margaret is not how she can avoid a loss to democracy but how she can, on balance, minimize this loss.

Both Justice Process' and Justice Results' views can be reconstructed so as to recognize that there will be a loss regardless of how Margaret decides. Both could argue that while outcomes and procedures matter, the democratic theorist must always prioritize one of these two aspects of democracy when they conflict. Process could claim that majoritarian procedures are always more fundamentally important from the standpoint of democracy than any loss to the core values that results from bad democratic outcomes. Therefore, he could argue that the right to participate in majoritarian procedures must always be upheld. At the same time, Results could argue that although there is a loss to democracy when majoritarian positions are overturned, the need to protect against bad democratic outcomes is more fundamental than the right to participate. On these grounds, Results could retain her position that majoritarian procedures should always be overturned when the result 
is an outcome that negatively impacts democratic values in any way. Since this version of Results' view gives no overwhelming weight to an intrinsic value of procedure, it follows that any bad democratic outcome would be reason to overturn a majoritarian procedure. ${ }^{11}$

Process' reconstructed view is impure in that it admits that outcomes can have moral weight according to the core values, yet it retains his commitment to proceduralism by refusing to allow for instances in which bad outcomes require overturning majoritarian procedures. ${ }^{12}$ In the same way, Results' reconstructed view is impure in that it admits majoritarian procedures have moral weight according to the core values, yet retains its commitment to democratic outcomes by refusing to admit that they can ever be trumped by a concern for majoritarian procedure. The problem here is that Results' view cannot explain why participation should trump undemociatic outcomes, even when the outcomes represent a trivial loss to democracy. Certain zoning restrictions might fit this description. For instance, one could argue that a law that prohibited holiday lights of a certain brightness inhibits one's autonomy and freedom of expression and thus constitutes an undemocratic outcome. If one thinks zoning decisions even in trivial matters negatively impact the core value of autonomy then, according to the impure outcomes based theory, this will always require an override of majoritarian zoning ordinances. This implication highlights how even the impure outcomes based approach gives insufficient attention to the intrinsic value of majoritarian procedures.

Less trivial examples also highlight why impure outcomes based views do not give enough weight to the intrinsic value of majoritarian procedures. For example, even if one were to concede that certain minimal economic welfare rights were necessary outcomes in a democracy (Beetham, 1999), there would still be a question of whether majoritarian procedures that failed to guarantee these rights should be overturned. If there is reasonable disagreement about how best to secure these rights, the intrinsic value of majoritarian procedures might be reason enough not to overturn legislation that failed to guarantee these rights.

These impure versions of proceduralism and democratic outcomes accounts have similar flaws. The problem lies in the fact that these theories have already admitted that the core values of democracy can be manifested within both procedures and outcomes. This is a clear recognition that both outcomes and procedures have some weight. Unless these theorists fall back again upon a pure procedural or outcomes based view, this recognition undermines the strong claim that the decision is to be made solely on the basis of whether it is majoritarian or results in a democratic outcome. At a minimum, these 'impure' theories should leave open the possibility that in a particular instance either outcomes or procedures might be more decisive in light of the core values, but they do not.

In contrast to these impure theories, my account not only accords moral weight to both procedure and outcome; it also commits me to the possibility that for any given case, the balance may need to be struck either in favor of a particular majoritarian procedure or in defense of a democratic outcome. The pure proceduralist theory, while perhaps wrong, is nonetheless internally consistent in denying any moral weight to outcomes and in denying that the protection of a good democratic outcome could necessitate overriding a procedure. A similar point holds for the 
pure outcomes view. But if an outcome can have weight because it affects the core values, the most theoretically plausible view (barring some additional argument) ${ }^{13}$ would leave open the possibility that this weight might be enough to require an override of the right to participate. It would also allow for the opposite possibility: that in some cases, the outcome does not sufficiently threaten core values, so that, the most democratic decision is the one resulting from democratic procedure.

At this point critics might object that I have abandoned the chief virtue present in both the pure procedural and pure outcomes based view. Both of those accounts offer a simple way of determining whether a decision is democratic. One claims we should look to outcomes, the other to procedure. In contrast, my view leaves us only with the assertion that we need to balance. But ease of decision-making is not the chief virtue in normative political theory. The evaluation of what is the most democratic decision inevitably involves a balancing of democratic values. Moreover, transparency about value conflicts should be counted as a virtue that cannot be ignored for simplicity's sake.

A strategy for balancing democratic outcomes and democratic procedure can be found in the United States Supreme Court's current approach to judicial review. Although it is not couched in democratic terms, the Court offers a model for balancing majoritarian procedures with individual rights, and the Court's practice can help answer the challenge that it is too impractical to balance democratic outcomes and majoritarian procedures. Court practice is to regard legislation that has passed through legitimate procedures as presumptively valid. If there is a 'rational purpose' to a law, which means primarily that it is not based in animas, the Court assumes it is valid when all procedures that are necessary to legal enactment have been followed. But when legislation is deemed to be in the category of a basic rights violation - for example, that of substantive due process - the Court presumes it is invalid. Here the burden is on the defenders of the law to show 'compelling interest' for overriding the presumption and allowing the law to stand. In a similar way, justices in Margaret's position can recognize the right to participate by presuming majoritarian legislation is valid on democratic grounds. But when a democratic rights violation has occurred through majoritarian procedure, the right can be given weight by presuming the legislation invalid.

\section{The Flaws with Formal Democratic Arguments and the Need for Examples in a Theory of Democracy}

In the previous section, I demonstrated the limitations of a purely procedure based or purely outcomes based theory. The following chart helps to elucidate this point. Each of the four quadrants represents a possible combination that could characterize a legislative enactment left to stand or a legislative enactment overridden by the Courts. I sort such enactments according to whether they have been passed by a majoritarian procedure and enacted into law (quadrants 1 and 2) or overridden by courts and thus struck down (quadrants 3 and 4). Such a process is not only non-majoritarian but also counter-majoritarian in that it happens after a majoritarian institution has given its authorization to a particular law. At the same time that decisions are grouped by their procedure, they are also grouped by whether or not their content is such that it would constitute a democratic outcome. I 
classify democratic outcomes, as I have done throughout this essay, as those that manifest the values at the core of democracy, and non-democratic outcomes as those that undermine these values.

Both the pure procedural and pure outcomes accounts of democracy suggest that whether or not a procedure is democratic depends entirely on which quadrant a decision falls into. I suggest in the rest of this section that this characteristic makes both theories too formal. Take, for instance, the pure procedural theory. On this account, the question of whether a decision is democratic depends entirely on whether it is in quadrants 1 or 2 , in which case it is democratic, or in quadrants 3 or 4, in which case it is not. The problem with this theory is that it cannot account for the fact that there are differences in democratic legitimacy between examples that fit within either the quadrant 1 and 2 pair or the quadrant 3 and 4 pair. I argued, for example, against the pure procedural theory stating that instances in which majoritarian plebiscites affirm core democratic values are more democratic than instances in which a majority undermines the core values. There is a more democratic decision present in quadrant 1 than in quadrant 2. Similarly, the pure proceduralist cannot account for the difference between instances in which a plebiscite is overruled for good democratic reasons and instances in which it is overruled for bad democratic reasons. The pure procedural theory thus cannot account for distinctions between democratic legitimacy in quadrants 3 and 4 .

Similarly, there is a problem with pure outcomes-based theories since they cannot account for the loss to democracy that occurs when a court is needed to affirm a democratic outcome. On this account, the question of whether a decision is democratic depends entirely on whether it is in quadrants 1 or 3, in which case it is

Table 1: Procedure versus Outcomes in Political Decision Making

Non-Democratic

Democratic Outcome

Outcome

Majoritarian:

Plebiscite

Counter-Majoritarian:

Plebiscite

Overruled
1. Majorities ratify democratic outcome. Core values reflected in both procedure and outcome.

3. Plebiscite overruled in order to prevent outcome that undermines core values. Core values undermined in procedure, but reflected in final outcome.
2. Majorities produce outcomes that violate democratic values. Core democratic values reflected in procedure, but not in outcome.

4. Plebiscite overruled for bad democratic reasons with the result that the core values are undermined by both procedure and outcome. Instance of nondemocratic procedure and non-democratic outcome. 
democratic, or in quadrants 2 or 4 , in which case it is not. The pure outcomes theory, therefore, can make no distinction between examples that fit in quadrants 1 or 3.

The more sophisticated impure variants of procedure and outcomes theories also have limitations made evident by the chart. The impure procedure based theory cannot acknowledge that in some instances the impact of a bad democratic outcome could be so great that it would require overriding a plebiscite. In terms of the chart, even this impure theory fails to recognize that a decision in quadrant 3 may be more democratic than a decision in quadrant 2. For example, the impure theory neglects that it is a democratic decision to override so-called 'miscegenation' laws. Similarly, the impure outcomes based theory cannot recognize that sometimes decisions impacting core values negatively should not be overturned because majorities deserve some deference. The impure theory cannot recognize that quadrant 2 decisions are sometimes more democratic than quadrant 3 decisions. For example, if one thinks zoning ordinances that restrict Christmas lights negatively impact the core value of autonomy, according to the impure outcomes based theory this will always require an override of majoritarian zoning ordinances.

So far I have discussed a hypothetical example in which a jurist and democratic theorist, Margaret, faces the decision of whether to strike down a majoritarian plebiscite in order to make, on balance, a more democratic decision. The simplicity of the hypothetical example helps explain why there are democratic elements to both majoritarian procedures and democratic outcomes. But the conflicts within actual institutions in the United States do not directly match Margaret's dilemma of whether to strike down a plebiscite. Congress, for instance, is not equivalent to a plebiscite, although the right to participate is used to select representatives. Rather, Congress is a representative institution that sometimes reflects and sometimes does not reflect the actual views of persons within the polity. At the same time, while the Court sometimes justifiably acts counter to the majority of persons' actual views, sometimes it too is a representative institution (Eisgruber, 2001). This observation can be linked in part to the fact that Congress appoints justices. In the rest of this section, I draw on actual Supreme Court cases to demonstrate the complication that arises in applying Margaret's hypothetical dilemma and the democratic solution I have crafted to actual institutions. While at times the Court acts in a counter-majoritarian way in order to preserve the core values, at times it also protects majoritarian institutions against counter-majoritarian policies. As I have argued, the Court rightfully protects majoritarian decision-making when these decisions do not threaten basic democratic rights. Therefore, the Court can act democratically in two senses. At times it strikes the balance between procedural and substantive values in favor of individual rights, and at times it protects majoritarian decision-making in the name of democracy.

In order to illustrate how the Supreme Court can act democratically by counteracting majoritarian decision-making, one need look only to the case of Loving $v$. Virginia (1967). In this case, the Supreme Court struck down legislation endorsed by a majority of Virginians that prohibited interracial marriage. The Court argued that this prohibition undermined the substantive due process right to make indi- 
vidual autonomous decisions in intimate matters. It also argued that the law violated the citizens' right to equal protection. I have suggested, in an independent argument, that one should understand both of these values as essential to the idea of democracy. The Court's appeal to substantive due process is best understood as an appeal to autonomy, while equal protection can be understood in terms of the core value of equality of interest.

The threat that the Virginian law posed to these values was more significant to the status of democratic citizens than any particular right to participate. The law undermined the value of autonomy by striking at what is arguably the most important decision in one's life, thus demeaning any future decisions a citizen might make. It struck directly at the value of equality by giving legal sanction to racial bigotry. Finally, it undermined the idea of reciprocity by denying the ability of citizens to offer a public recognition of one another's autonomous decision-making by limiting citizens' ability to legally recognize each other's marriages. Because this legislation is at odds with these democratic values, the decision to strike down the Virginia law was a gain to democracy. This is true despite the admitted loss that came from overriding a state law passed by representatives ostensibly (and probably actually) speaking for real citizens.

The general point suggested by the example of Loving is that legislative bodies, even when they enact the will of the majority of their constituents, can act undemocratically because they threaten the core values at the basis of the democratic ideal. In such cases, counter-majoritarian institutions such as courts, which do not represent majority will, act in a democratically legitimate manner when they strike down such laws. I have used the American case as one example, but this phenomenon extends to other cases of counter-majoritarian judicial review. For example, the South African constitutional court acts democratically when it strikes down legislation that threatens to undermine the core values of democracy, regardless of whether it is popular. The South African constitutional court arguably acted democratically when it struck down legislation that interfered with sexual intimacy among gay couples in National Coalition for Gay and Lesbian Equality v. Minister of Justice (1999) (for a discussion of this decision, see Williams, 2004).

Judicial review can also be used for non-democratic purposes. For example, the United States Supreme Court acts undemocratically in cases in which it strikes down popular legislation that does not threaten the core values of democracy. In Lochner v. New York (1905), the Court overturned popular legislation that limited the hours of bakers. It did so in the face of a movement among a majority of people to increase the autonomy of workers by ensuring some room to have a life outside of work. Arguably, the Court acted undemocratically in two senses. First, there was a loss to democracy insofar as the Court counteracted a majoritarian decision. In this sense, its action was similar to that in Loving. But unlike Loving, in this case the Court arguably undermined rather than promoted the core values of democracy. (My own view, developed in another place, is that the core value of political autonomy should, in a democracy, be given worth by ensuring that all citizens have the resources to exercise their autonomy. ${ }^{14}$ ) At the time of Lochner, citizens appear not to have had sufficient guaranteed resources to give them guaranteed autonomy, and so efforts to reduce working time are best understood as efforts to increase autonomy in the face of the lack of resources. Thus Lochner, because it 
impeded these efforts, was not a justifiable democratic override of a majoritarian decision. The difference lies in the substance of the decision.

The Lochner era is often used as an example of the danger of judicial review and its potential to undermine economic rights for citizens. But on my account, the Lochner Court can be criticized because it undermined democratic outcomes, not because there is something inherently wrong with judicial review. The general point is that counter-majoritarian instances are illegitimate when they use their power to act against fundamental democratic principles. The potential illegitimacy of the Court is further enhanced when it strikes down democratic procedures that aim toward advancing these rights. The danger seems acute in the American case because of the Court's history in the early 20th century of illegitimate action. In South Africa this danger is counteracted by the Constitution's explicit appeal to economic rights that would clearly prohibit Lochner type decisions. But of course in South Africa and in any constitutional regime, the danger still exists that courts will exercise judicial review in a way that undermines basic democratic rights. ${ }^{15}$

In Loving, the Court struck down legislation on grounds that could have been expressed in democratic terms because legislation prohibiting interracial marriage is a fundamentally anti-democratic outcome. Sometimes, however, the Court acts democratically not because it protects democratic outcomes but because it protects democratic procedures. In these cases, the Court should oppose state legislatures and Congress in order to affirm citizens' procedural right to participate. Arguably, this is what takes place when the Court strikes down legislation that undermines the principle of 'one person, one vote'. ${ }^{16}$ In contrast to instances where the Court acts democratically by striking down majoritarian procedures, in these instances the role of the Court is democratic because it defends majoritarian procedural guarantees.

A more complicated question concerns the relationship between representative institutions, the Supreme Court, and the right to participate. For example, consider the dilemma that the court has faced in adjudicating federalism cases. ${ }^{17}$ In some of these cases, the court asks whether Congress has the authority to preempt (or in other words overrule) majoritarian decisions of states or other localities. In some of these decisions, when the court upholds the decision of smaller governmental units against Congressional decisions, it can be said to protect the decisions of local majorities against Congress. The Court's decisions in these cases can potentially be defended on the grounds that they accord majoritarian decisions greater weight than any potential gain that might be brought about by the substantive outcomes of Congressional decisions, assuming the congressional outcomes to be more substantively democratic than the local decisions.

So far I have suggested that the Court strikes down legislation on democratic grounds for two reasons. First, as in Loving, it can override representative as well as majoritarian decisions when a fundamental democratic right is at stake. Second, as in the federalism cases, it can act in defense of the right to participate when this right is more fundamental than the negative impact of a policy on the core values of democracy. ${ }^{18}$ A good theory of democracy needs to recognize that a democratic evaluation requires a balance between the protection of the core values and the protection of majoritarian procedures. In practice, the Supreme Court of the United States has the potential to uphold substantive democratic rights when majorities threaten them. In addition, it can affirm the right to participate when representa- 
tive institutions such as Congress challenge it. But an appropriate evaluation of whether the Court has acted democratically depends on the substantive issue at stake and its relationship to the core values of democracy.

\section{The Objection from Benevolent Dictatorship}

Critics might object that nothing in my theory requires that rights be enforced by an institution that is accountable to the public. In contrast, the United States Supreme Court is appointed by elected officials and therefore is at least indirectly accountable to the actual beliefs of persons who constitute the democratic public. On my account, however, justification depends on the substance of a particular decision. What would prevent these rights from being enforced by an unaccountable set of unelected guardians?

For example, we could imagine a judiciary intended to protect basic rights but unaccountable to either persons' actual decisions or the decisions of their elected representatives because this judiciary can choose its own successors. ${ }^{19}$ Similarly, we could imagine a situation in which an enlightened hereditary monarch has been entrusted to protect fundamental rights. Some might take it as a consequence of my view that I am committed to defending such institutions as democratic.

However, my claim that outcomes can be more or less democratic does not concern the authority that institutions have but rather whether a particular decision in its content can be more or less democratic. The implication is that institutions (both private and public) and officials (both unelected and elected) can work to bring about democratic outcomes that are more or less legitimate. The democratic legitimacy of decisions, therefore, is not solely about who is acting; it is also about what is decided. Institutions and powerful individuals who are not elected can be more or less democratic as a result of the outcomes they help to secure through both political participation and more indirect means.

Moreover, it is important to point out that judicial review differs from 'democratic dictatorship' in its structure. The aim of the institution is to preserve democratic outcomes and at the same time preserve popular participation in democratic processes. Neither the United States Supreme Court nor the Constitutional Court of South Africa dictates policy. Rather, the process of judicial review involves striking down legislation that can then be debated once again and reformulated by majoritarian institutions. This process is better understood as a conversation or dialogue between the Court and legislative majorities. The possibility exists in such a process for majorities to achieve their legislative goals yet respect basic rights with guidance from the Court.

I do want to concede that a dictator can bring about outcomes that are more or less democratic. But nothing in this claim implies that democratic outcomes are sufficient for democratic legitimacy. Dictatorship entirely ignores the intrinsic value of actual persons making decisions. I contend that a regime holding such a view would undermine democratic legitimacy by failing to recognize an essential aspect of the core values. The objection that my account of democracy is compatible with a dictatorship is valid only to the extent that my account allows for the distinction 
between dictators, or unaccountable elected officials, who make democratic decisions and those who do not. However, my account also explains why a benevolent dictatorship would lack an essential aspect of democratic legitimacy.

\section{Conclusion}

The view I have defended identifies and embraces the tension between procedure and outcomes. I do not seek to resolve this fundamental tension in favor of a narrowly procedural or narrowly substantive conception of democracy. Rather, I have shown why the idea of self-government requires a balance of both the procedural right to participate and a concern to protect substantive individual rights. On the one hand, it explains why the democratic tradition rightly engages persons in majoritarian processes, where they are free to make decisions about policy. It therefore grants recognition to the intrinsic value of majoritarian procedure commonly associated with democracy. Yet, at the same time, it demonstrates why some majoritarian decisions can be not only unjust but also undemocratic. For instance, when a majority violates the privacy rights of individuals (as it did in the Texas legislation at issue in Lawrence) or violates their right to free expression, its decision is rightly overridden through the process of judicial review in the name of democracy. Such counter-majoritarian decisions by the Courts can be justified directly be reference to the core values of democracy. This conclusion is meant to be a general claim about the legitimate role of counter-majoritarian institutions in a democracy. In addition to legitimizing the judicial review in the US context, it also suggests why constitutional courts such as South Africa's can be understood as democratic.

Although political scientists and political theorists have often defined democracy in terms of institutions and procedures, my own view suggests why it is impossible to understand democracy's value independent of specific policy controversies. I have argued for the necessity of balancing the intrinsic worth of democratic procedures with the effect of specific policy outcomes on the core values. I leave the next step - an argument about which substantive rights are central to democratic legitimacy - for another place.

(Accepted: 18 August 2004)

\section{About the Author}

Corey Brettschneider, Department of Political Science and Taubman Center for Public Policy, 67 George Street, Box 1977, Brown University, Providence RI 02912, US; email: Corey_Brettschneider@Brown.edu

\section{Notes}

For comments and discussion I am thankful to David Estlund, Amy Gutmann, Alon Harel, George Kateb, Loren King, Robert Post, John Tomasi, and Mariah Zeisberg. I am also thankful to Chris Eisgruber for encouraging me to address many of the issues in this paper. For research assistance I am indebted to David Grant, Paul Neufeld, and Connie Wu.

1 There is debate over what else besides the right to vote counts as a procedural right. Much of this work draws on Mieklejohn (1948) and Ely (1980). 
2 For a procedural defense of democracy with reference to an account of equal political resources, see Christiano (1996). Waldron (2001) defends a specifically majoritarian procedure.

3 My project shares this general view with Joshua Cohen (1997) as well as Gutmann and Thompson (1996).

4 For an elaboration of why these values constitute the core meaning of democracy, see Brettschneider (forthcoming). By 'equality' I refer to the broad notion that citizens' interests should count equally, and by 'autonomy' to the notion that individuals have a right to participate in ruling the polity but also to the substantive aspect of the notion in that the outcomes of these procedures should not undermine citizens' capacity to view themselves as rulers. I draw on both Jeremy Waldron's procedural understanding of these values (2001) as well as Ronald Dworkin's substantive understanding (1996).

5 Ronald Dworkin (1996) includes rights to free speech and privacy as essential to democracy but rejects the idea that economic rights are essentially democratic. David Beetham (1999), however, takes a broader approach and includes economic rights as democratic outcomes.

6 Again, this hypothetical is meant to illustrate the tension between democratic procedures and democratic outcomes. I turn to an application of this hypothetical to the American case of judicial review in a later section.

7 For Dworkin this entails that democratic outcomes have three characteristics. In his words: 'A political community cannot count anyone as a moral member unless it gives that person a part in any collective decision, a stake in it, and independence from it' (1996, pp. 24-6). My argument in this section draws heavily from Waldron. Waldron considers Dworkin's position when the Court strikes down majoritarian legislation in the following terms: 'Is there a loss to democracy? The answer, Dworkin says, depends entirely on whether the Court made the right decision' (Waldron, 2001, p. 291).

8 Dworkin (1996) shares my interest in protecting fundamental democratic values. However, as argued above, Dworkin overstates the importance of equality and my focus in the pages that follow is on why he neglects procedural aspects of the core values. For more on this see my response to the benevolent dictatorship objection in the fourth section above.

9 I develop this value theory of democracy in greater depth in Brettschneider (forthcoming).

10 See Waldron (2001), Chapter 11 'Participation: The Right of Rights' for the capacity argument: 'The attribution of any right, I said, is typically an act of faith in the agency and capacity for moral thinking of each of the individuals concerned' (Waldron, 2001, p. 250).

11 Outcomes theorists, however, might point to instrumental reasons (for instance, instability) for not overturning the outcomes of majoritarian procedure.

12 By moral weight I mean significance, but this does not mean that anything that has weight will be cause for a particular decision. In this sense moral weight is pro tanto. Jeremy Waldron (2001) could be read to embrace this 'impure' view.

13 I will consider one such argument below but find it wanting.

14 See Brettschneider (manuscript). My aim, however, in this essay is not to defend this relationship between resources and autonomy. One could reject this particular example but still find acceptable the argument of this essay about the relationship between substantive rights and procedure.

15 For a discussion of economic rights and South African Constitutionalism, see Patrick Lenta (2004).

16 See Baker v. Carr, 369 U.S. 186 (1962) and Reynolds v. Sims, 377 U.S. 553 (1964).

17 The federalism cases considered by the court focus largely on the legal issue surrounding the power granted to congress by the commerce clause. In contrast, I am interested in the democratic question raised by these issues. For an example of the legal issues, see: U.S. v. Morrison, 529 U.S. 598 (2000).

18 A distinct issue concerns whether Constitutional amendments passed according to fair procedure could themselves be struck down on the grounds that they are not democratic. Arguably the burden here would be greater than that at issue in majoritarian legislation because more than a majority of citizens must endorse such amendments. For an inquiry into a similar question, see Murphy (1980).

19 I take this criticism and these examples from Chris Eisgruber's response to my paper on the panel 'Substance of Democracy' held at the American Political Science Association conference in Philadelphia in 2003.

\section{Cases}

Baker v. Carr, 369 U.S. 186 (1962).

Lawrence v. Texas, 123 U.S. 2472 (2003). 
Lochner v. New York, 198 U.S. 45 (1905).

Loving v. Virginia, 388 U.S. 1 (1967).

National Coalition for Gay and Lesbian Equality v. Minister of Justice, 1 SA 6 (CC) (1999).

Reynolds v. Sims, 377 U.S. 553 (1964).

Stanley v. Georgia, 394 U.S. 557 (1969).

Texas v. Johnson, 491 U.S. 397 (1989).

U.S. v. Morrison, 529 U.S. 598 (2000).

\section{References}

Beetham, D. (1999) Democracy and Human Rights. Cambridge: Polity Press.

Bickel, A. M. (1962) The Least Dangerous Branch. Indianapolis IN: Bobbs-Merrill.

Brettschneider, C. (manuscript) Democratic Rights: The Substance of Self-Government.

Brettschneider, C. (forthcoming) 'The Value Theory of Democracy,' Philosophy, Politics, and Economics.

Christiano, T. (1996) Rule of The Many. Boulder CO: Westview Press.

Cohen, J. (1997) 'Deliberation and Democratic Legitimacy', in W. Rehg and J. Bohman (eds), Deliberative Democracy. Cambridge MA: MIT Press, pp. 67-92.

Dworkin, R. (1996) Freedom's Law. Cambridge MA: Harvard University Press.

Eisgruber, C. (2001) Constitutional Self-Government. Cambridge MA: Harvard University Press.

Ely, J. H. (1980) Democracy and Distrust. Cambridge MA: Harvard University Press.

Estlund, D. (1997) 'Beyond Fairness in Deliberation: The Epistemic Dimension of Democratic Authority', in W. Rehg and J. Bohman (eds), Deliberative Democracy. Cambridge MA: MIT Press, pp. 173-204.

Estlund, D. (forthcoming) 'Democratic Theories' Flight from Substance', in M. Smith and F. Jackson (eds), Oxford Handbook of Contemporary Philosophy. Oxford: Oxford University Press.

Friedman, B. E. (1998) 'The History of the Countermajoritarian Difficulty, Part One: The Road to Judicial Supremacy', New York University Law Review, 73 (2), 333-433.

Gutmann, A. and Thompson, D. (1996) Democracy and Disagreement. Cambridge MA: Belknap Press of Harvard University.

Habermas, J. (1998) Between Facts and Norms. Cambridge MA: MIT Press.

Harel, A. (2003) 'Rights-Based Judicial Review: A Democratic Justification', Law and Philosophy, 22 (3-4), 247-76.

Lenta, P. (2004) 'Democracy, Rights Disagreements and Judicial Review', South African Journal on Human Rights, 20 (1), 1-31.

Michelman, F. (1988) 'Law's Republic', Yale Law Journal, 97 (8), 1493-1537.

Mieklejohn, A. (1948) Free Speech and Its Relation to Self-Government. New York: Harper.

Murphy, W. (1980) 'An Ordering of Constitutional Values', Southern California Law Review, 53 (2), 703.

Waldron, Jeremy (2001) Law and Disagreement. Oxford: Oxford University Press.

Whittington, K. (unpublished) 'Preserving the "Dignity and Influence of the Court": Political Supports for Judicial Review in the United States'.

Williams, K. (2004) “I do" or "We Won't": Legalizing Same-Sex Marriage in South Africa', South African Journal on Human Rights, 20 (1), 32-63. 